\title{
Nutrient export to an Eastern Atlantic coastal zone: first modeling and nitrogen mass balance
}

\author{
Mathieu Canton ${ }^{\mathrm{a}}$, Pierre Anschutz ${ }^{\mathrm{a},{ }^{*},}$, Alexandra Coynel ${ }^{\mathrm{a}}$, Pierre Polsenaere ${ }^{\mathrm{a}}$, Isabelle Auby ${ }^{\mathrm{b}}$ and \\ Dominique Poirier ${ }^{\mathrm{a}}$
}

\author{
a Université de Bordeaux, CNRS; UMR 5805 Environnements Paléoenvironnements Océaniques (EPOC), avenue \\ des facultés, 33405 Talence, France \\ ${ }^{\mathrm{b}}$ Laboratoire IFREMER DEL/AR, 33120 Arcachon, France \\ *: Corresponding author : Pierre Anschutz, email address : p.anschutz@epoc.u-bordeaux1.fr
}

\begin{abstract}
:
We have studied $15 \mathrm{c}$ atchments supplying freshwater to a F rench Atlantic coastal lagoon, where increase in nitrogen loads due to agriculture is supposed to have destabilized the ecosystem in the last decades. The catchment is a lowland composed of Pleistocene sands with an average slope of $0.25 \%$. To study the nutrient export in relation to land-use surface waters were sampled bi-weekly between October 2006 and $\mathrm{J}$ anuary 2009 and land-use was established by plane photographs and Geographic Information System (GIS). Cultivated pine forests represent more than $80 \%$ of the total surface and $7 \%$ of the catchment area has been deforested recently. Significant areas of some catchments are used for maize crop. Housing is confined to the coastal zone. Maize and forest crop give a robust signature in terms of nitrate export. In view of modeling the nutrient fluxes, we have established the mean export rate for every land-use: forested parcels, deforested parcels, cultivated surfaces, and housing areas export $45,93,2850$, and $61 \mathrm{~kg} \mathrm{~N}$-nitrate $\mathrm{km}^{-2}$ year ${ }^{-1}$, respectively. Exports of ammonium, dissolved organic $\mathrm{N}(\mathrm{DON})$, and dissolved inorganic $\mathrm{P}$ (DIP) could not be related to land use. The mean export is 13,100 , and $0.57 \mathrm{~kg} \mathrm{~km}^{-2}$ year ${ }^{-1}$ for $\mathrm{N}$-ammonium, DON, and DIP, respectively. The modeling of nitrogen flux is in good agr eement with our measures for the largest catchment, which supplies about $90 \%$ of the total continental DIN flux. However, small catchments are more dynamic due to hydrological conditions and the model is less accurate. This work has permitted to complete and unify scattered studies about nutrient cycling in this area. Thus we have established and compared the nitrogen budget of cornfields and cultivated pine forest. We have emphasized that (i) fertilizer use should be reduced in cornfields because they stock between 200 and $6400 \mathrm{~kg} \mathrm{DIN} \mathrm{km}^{-2}$ year $^{-1}$, and (ii) the nitrogen budget in pine forest mostly depends on tree harvesting and symbiotic $\mathrm{N}$-fixation, which is poorly constrained. Export of $\mathrm{N}$ by rivers represents a small contribution to the $\mathrm{N}$ budget of soils.
\end{abstract}

Keywords: Nitrogen - Phosphorus - River export - Land use - Coastal catchment - Arcachon Bay Modeling - Mass balance

\section{Introduction}

Littoral ecosystems such as lagoons and salt marshes are some of the most productive environments of the global ocean (Falkowski et al. 1998). Coastal areas represent $40 \%$ of total ocean biologic production, whereas they represent only $10 \%$ of oceanic area (Mantoura et al. 1991). They are powerful biogeochemical reactors and the inner reactions may have global consequences on carbon and major nutrient cycle. About $87 \%$ of the Earth's land surface is connected to the ocean by rivers (Ludwig and P robst 1998) and a s a consequence, littoral ecosystems receive continental waters, which may be impacted by human activities, and sometimes severely polluted (Billen et al. 2007; Meybeck and Helmer 1989). Anthropogenic inputs of biologically available $N$ and $P$ into terrestrial landscape in the form of artificial fertilizers through cultivation of $\mathrm{N}$ fixing crops, via fossil fuel burning, and waste water have caused the accumulation of excess nutrients in continental ecosystems. One of the common 
1 disturbances is eutrophication, which is defined as the enrichment of waters with plant 2 nutrients, mainly phosphorus and nitrogen (Meybeck \& Helmer 1989), primarily nitrogen in marine ecosystems (Howarth \& Marino 2006). The trophic imbalance provokes an ecological feedback (Howarth 2008; Smith 2003), such as plant growth, which results in visible blooms (floating algal mats) and potential toxic microalgae development (Conley et al. 1993). Decomposition of plant material leads to depletion of oxygen and subsequently fish mortality and decrease in $\mathrm{pH}$. As a global consequence, biodiversity is always reduced because of eutrophication (Galloway 2003). A recent work has shown that the number of hypoxic zones in the coastal margins is doubling every decade (Diaz \& Rosenberg 2008).

Shallow coastal bays and lagoons are highly sensitive to eutrophication because they are particularly vulnerable to the rapid changes in population and land use occurring in the coastal zone (Duarte 1995; Nixon et al. 2001; Valiela et al. 1998). Moreover they are important sites for human activities, such as tourism, food resources production (oysters, mussels, clams, shrimps, fishes, salt), and waste dumping, which make these environments vulnerable. Some of these uses are not compatible. The objective of sustainable management is to derive benefits from such exploitations, without affecting the long-term quality of the environment. In this view, several studies have been performed about the larger French coastal lagoon (Arcachon Bay) and its catchment. It was established that the increase in intensive agriculture and nitrogen fertilizer use might destabilize the Arcachon Bay ecosystem (Auby et al. 1994) and macroalgae proliferations was observed during the eighties. Moreover a recent study has highlighted the regression of Zostera noltii meadows (Plus et al. 2010) even though these meadows buffer the nutrient loads and limit the eutrophication risk of the Arcachon Bay (De Wit et al. 2001). As a consequence it was necessary to update the nutrient budget originating from continent.

The first purpose of this study was to obtain for the first time and for the entire catchment the nutrient budget and land-use data. In this view we have studied the dissolved organic and inorganic forms of nitrogen and phosphorus of 15 catchments. We have compared the obtained budget with previous ones (e.g. Auby et al. 1994) in order to rely the evolution of the nutrient supply with the eutrophication history of the Arcachon Bay. Secondly, we aim to establish a model of nutrient export based on land-use. The third objective was to compile several partial studies concerning the nitrogen cycle in the Arcachon Bay catchment. This review permitted to establish the nitrogen mass balance in cultivated pine forests and cornfields in order to discuss the sustainability of this cultivation. 


\section{Studied site}

The Arcachon Bay $\left(44^{\circ} 40^{\prime} \mathrm{N}, 01^{\circ} 10^{\prime} \mathrm{W}\right)$ is a $156-\mathrm{km}^{2}$ lagoon located in the French Atlantic coast. The tide amplitude oscillates between 1.1 and $4.9 \mathrm{~m}$. The internal part of the basin emerges at low tide $\left(115 \mathrm{~km}^{2}\right)$. The intertidal zone covers $66 \%$ of the surface area. It encloses the largest seagrass meadow of Zostera noltii in Europe (Auby \& Labourg 1996). The catchments are a typical lowland, with an average slope of $0.25 \%$. The catchment has a surface of $3001 \mathrm{~km}^{2}$ and is drained by the Leyre River and by 15 small streams, which are direct tributaries to the lagoon. The geology of the Arcachon Bay catchment consists of an uniform quaternary sand cover (Legigan 1979). The aquifer is a multi-layered system, highly connected. The shallow phreatic aquifer is called the "Sable des Landes". The water table is not deeper than $3 \mathrm{~m}$ and the total thickness does not exceed $25 \mathrm{~m}$. It is formed by a homogeneous sand formation. Its bottom consists of a sandy clay layer. Despite high hydraulic conductivity of sands, the groundwater velocity is less than $50 \mathrm{~m}^{\text {year }}{ }^{-1}$, because of the small slope between 2 and 4\%o (Rimmelin 1998; Saint Pe 1966).

\section{Methods}

\section{Catchment boundaries, soil occupation, and river discharge}

Catchments studied have been delimited and detailed by Laplana et al. (Laplana et al. 1992). Soil occupation has been determined by remote sensing using map of the French institute IGN and aerial photographs analyzed with the Geographic Information System (GIS) ArcGIS.

The daily water discharge of the Leyre River is provided by the French public institute of regional environment (DIREN). The discharge is measured at a gauging station with an automatic lymnimeter. We use the product of the Leyre River specific discharge by the surface area of the other streams to estimate their discharge. This extrapolation technique can lead to a large error when geology and slope of the catchment change, which is not the case here. The average slope is about $0.25 \%$ and the catchment and the aquifer are constituted by 
1 a homogenous and thick sand formation (Legigan 1979). Comparison of the extrapolation

2 techniques with real flow measurement made on two rivers (Leyre and Tagon) in 2005 gave

3 good results. The flow of small rivers could be overestimated by about $30 \%$ at the annual

4 scale. Flood and low water level are more dynamic in small catchments and badly estimated

5 by interpolation. However for our study it is a sufficient approximation, because the

6 cumulative flow of all the small rivers represents $22 \%$ of the Leyre River flow.

\section{Sampling}

We have studied the 15 streams of the Arcachon Bay catchment. The sampling stations were located near the river mouth but upstream the dynamic estuary to exclude marine influences. The sampling frequency was at least two samplings per month and up to four samplings per month in the three main streams (Leyre, Cires and Milieu). This choice permits to have a proper representation of meteorological events and seasonal contrasts linked to soil occupation in farming catchments. The year 2007 was a complete sampling year, and 2008 was limited to the nine major streams. The sampling provided a continuous series to study annual flows. In addition, the French institutes SIBA and IFREMER supplied data of the Leyre quality from a survey between 1971 and 2008 (Auby et al., 1994 and unpublished data). The sampling frequency was two samplings per month. For inorganic nutrient determination two $12 \mathrm{ml}$ samples were collected near the riverbank using a $50 \mathrm{ml}$ syringe and samples were filtered in situ with $0.20 \mu \mathrm{m}$ cellulose acetate syringe filters. Filtered samples were stored in polypropylene tubes in darkness at $-18^{\circ} \mathrm{C}$ for a few days before analyses. Samples for organic nutrient determination were filtered on GFF filters and stored in glass tubes at $-18^{\circ} \mathrm{C}$.

We collected 58 samples of rainwater after each precipitation event during 2008. Rainwaters collector was an opaque bottle fitted with a funnel. Rain waters were collected within few hours after rains using a $50 \mathrm{ml}$ syringe and were filtered with $0.20 \mu \mathrm{m}$ cellulose acetate syringe filters. Moreover three meteorological stations of Meteofrance covering the entire catchment provided data regarding the daily amount of rainfalls. We used the average of the three stations. 
The dissolved inorganic compounds were analyzed colorimetrically for river water and rainwater samples according to standardized techniques. Dissolved nitrates $\left(\Sigma \mathrm{NO}_{3}{ }^{-}=\mathrm{NO}_{3}{ }^{-}\right.$

$6+\mathrm{NO}_{2}{ }^{-}$) were analyzed by Flow Injection Analysis (FIA) according to Anderson (1979). Precision was $\pm 10 \%$ for $\Sigma \mathrm{NO}_{3}{ }^{-}$. Dissolved phosphate (DIP) and ammonium were measured by colorimetric procedures (Mullin \& Riley 1955; Murphy \& Riley 1962; Strickland \& Parsons 1972). The precision for these methods was $\pm 5 \%$ for DIP and $10 \%$ for $\mathrm{NH}_{4}{ }^{+}$. Total dissolved nitrogen (TDN) and phosphorus (TDP) were respectively measured as $\mathrm{\Sigma NO}_{3}{ }^{-}$and DIP after total oxidation by persulfate reagent according to Valderrama (1981). Dissolved organic nitrogen (DON) and phosphorus (DOP) are the difference between TDN and DIN, and between TDP and DIP, respectively. The error in DON is as high as $\pm 20 \%$ because it corresponds to the difference of two values that can be close. The error in DOP may be higher; the values are indicative and are treated as such. Total dissolved $\mathrm{N}$ and $\mathrm{P}$ were measured on river water samples only.

\section{Annual mean concentrations and annual nutrient fluxes}

The annual streamwater flux $\left(Q_{m}\right)$ is an arithmetic mean of the daily streamwater discharge. The annual flux of nutrients supplied by rivers $\left(F_{S}\right)$ is estimated using commonly applied equations (Meybeck \& Ragu 1997; Walling \& Webb 1985). First, we calculated the average annual concentration $\left(C_{m}\right)$ :

$$
C_{m}=\sum\left(C_{i} \cdot Q_{i}\right) / \sum Q_{i}
$$

where $C_{i}$ is the nutrient concentration at time $i$ and $Q_{i}$ is the streamwater flow at time $i$.

29 Then,

$F_{s}=C_{m} \cdot Q_{t o t}$

31 where $Q_{t o t}$ is the total streamwater discharge during one year. 
2 We calculated the annual flow of nutrient supplied by rainfalls $\left(F_{R}\right)$ with the same methods rate $E_{i}$ due to the land use $\mathrm{i}$ is calculated with the relation

$$
E_{i}=F_{i} / S_{i}
$$
use i. of urban area and few farming area. $F_{c}=\sum\left(S_{i} \cdot E_{i}\right)$

Export rates are defined according to the land use and average annual flux. The export

where $F_{i}$ is the average annual flux due to the land use i and $S_{i}$ is the surface area of the land

Since the catchments are heterogeneous, we must progress by stages. First, the nutrient export rate due to forest is calculated from the Aiguemorte catchment because it contains $90 \%$ of pine forests, only $3.3 \%$ of deforested parcel and no farming area. Secondly, the nutrient export rate due to deforested areas is calculated from the Cassy catchment, which has a significant part of deforested areas (19.3\%), no farming, and very few housing areas. For that we have subtracted the nutrient flux due to forest parcels and we have considered that the remaining flux is due to deforested parcels. Similarly, we have calculated the nutrient export rate due to farming parcels by subtracting from deforested and forest nutrient export rate in mixed land use catchments i.e. for Leyre, Cires, Milieu, and Passaduy. The nutrient export rate due to urban area was calculated from the La Teste catchment because it contains $59.8 \%$

Based on these average export rates, we computed the DIN flux $\left(\mathrm{F}_{\mathrm{c}}\right)$ defined as where $S_{i}$ is the mean surface of the parcel $i$ and $E_{i}$ is the DIN export rate of the parcel $i$. 
The mass balance budget enables to synthesize scattered data about nitrogen

2 biogeochemistry. Moreover it permits to compare the nitrogen cycle in the both ecosystems, cultivated pine forest and cornfields. The $\mathrm{N}$ cycle in agro-ecosystems depends on numerous processes; however, it can be simplified according to Galloway (1998; 2003) and Puckett (1999) as: (i) assimilation of DIN from fertilizer, manure, and atmospheric deposition into biomass; (ii) decomposition or mineralization of biomass to ammonium through ammonification and oxidation of ammonium to nitrate through nitrification; (iii) reduction of nitrate to $\mathrm{N}$ gas $\left(\mathrm{N}_{2}\right)$ through denitrification; (iv) conversion of $\mathrm{N}$ gas to ammonium by $\mathrm{N}$ fixing organisms through $\mathrm{N}$ fixation; (v) loss of ammoniac either to the atmosphere by volatilization; (vi) retention of ammonium on cation exchange sites or in clay interlayers; (vii) removal of $\mathrm{N}$ in harvested crops and animals; (viii) loss of DIN to ground water and river by leaching and run-off; and (ix) alteration of mineral.

This mass balance is based on data acquired during our survey and data from literature. Inputs of nitrogen due to fertilizer and atmospheric deposition (i) are well known. Atmospheric deposition is provided by the rainwater survey of the present study and the fertilizer use is provided by the French institute of agriculture (AGRESTE). No local data exist about ammonification and nitrification (ii) in these catchments. In the studied zone, maize is cultivated for grain and the both stems and leaves stay in situ after corn harvesting. We consider that this biomass is bioavailable and it is mineralized during the next year and then we estimate the biomass of stems and leaves. The total biomass of cornfield is estimated by the French institute of agriculture (AGRESTE 2000) and Plénet and Lemaire (1999). Sixty $\%$ of nitrogen in maize plant is located in grain and $40 \%$ in stems and leaves (Lemaire, personal communication). In a pine forest environment, we consider that ammonification and nitrification are negligible because vegetation is highly limited under mature pine forestry and pine needles are highly depleted in nitrogen. However, this simplification cannot be applied in deforested areas because ammonification of logging residues is high. In that case Loustau et al. (1999) have estimated the amount of nitrogen in barks. Denitrification (iii) in groundwater under cornfields has been studied by Rimmelin (1998) and De Wit et al (2005) and the mass balance budget is based on these data. We suppose that denitrification in forest is negligible due to unfavorable environment: low nitrate concentration (Loustau et al. 1999), and low labile organic carbon (De Wit et al. 2005). Moreover, denitrification is highly limited in sandy aquifer (Groffman \& Tiedje 1989). Symbiotic and non-symbiotic fixation of nitrogen (iv) has not been studied in this area. Cornfields do not permit high nitrogen fixation, hence we assess the fixation rate from literature in similar environments. In pine forests of the studied 
1 catchments, a significant symbiotic fixation is due to gorse Ulex europaeus. We can use a first

2 assessment based on estimated biomass and the natural ${ }^{15} \mathrm{~N}$ abundance method in gorse 3 (Augusto et al. 2005). Jambert et al. (1997) have studied the volatilization (v) in cornfields 4 and pine forest (Jambert et al. 1994) with chambers techniques; we use these data. We consider that sorption (vi) is negligible in both ecosystems because the cationic exchange capacity of soils is very low, estimated close to $1 \mathrm{meq}$ (Canton et al. 2010). Assessment of nitrogen loss due to harvesting (vii) is based on previous studies. Loustau et al. (1999) have studied pine harvesting and Plénet and Lemaire (1999) have studied maize harvesting. Loss of DIN due to leaching (viii) was estimated in the present study. We consider that mineral alteration (ix) is not a source of nitrogen because soils contains more than $90 \%$ of quartz 11 (Legigan 1979).

\section{Results}

17 18

Pine forests (Pinus pinaster) dominate the land use. They occupy more than $80 \%$ of the total surface (Fig. 1). Freshly deforested areas represent $7 \%$ of the land use (Fig. 1; Tab. 1). Intensive farming covers significant areas of some catchments. Housing is rather confined to the coastal zone except in the Leyre region (Fig. 1; Tab. 1). Aiguemorte catchment is dominated by forest $(89.5 \%)$ and contains a few deforested areas $(3.3 \%)$ and no farming areas. It defines the export rate of forested parcels. Cassy catchment has a significant part of newly deforested areas (19.3\%) and no farming areas. It defines the difference between the export rate of deforested parcels and that of forested parcels. Several catchments (Cires, Leyre, Milieu, and Passaduy) have a significant portion of farming areas and a few housing and deforested areas. They can characterize the export rate of farming parcel by difference with the previous export rates. About $70 \%$ of the farming areas are made up of cornfields. Vegetable and flower fields occupy about $30 \%$ of farming surfaces (AGRESTE 2000). The Ponteil River catchment is dominated by forestry and is characterized by the presence of a 0.4 $\mathrm{km}^{2}$ domestic waste landfill. 

stutied catchments. The mean concentration mask the variability of sampling. The standard deviation of nitrate concentrations is included between 30 and $80 \%$ for the overall stations but the major part is included between 40 and $60 \%$. Mean nitrate concentrations are between 0.11 and $2.70 \mathrm{mg} \mathrm{N} \mathrm{1}^{-1}$ in 2007, and 0.06 and $4.82 \mathrm{mg} \mathrm{N}^{-1}$ in 2008. Ammonium concentrations are less heterogeneous and less variable. Mean ammonium concentrations are included between 0.04 and $0.19 \mathrm{mg} \mathrm{N}^{-1}$ in 2007, and 0.06 and $0.10 \mathrm{mg} \mathrm{N}^{-1}$ in 2008. The Ponteil River is an exception with $2.45 \mathrm{mg} \mathrm{N}^{-1}$ in 2007 and $1.10 \mathrm{mg} \mathrm{N} \mathrm{1}^{-1}$ in 2008. Mean DON concentrations are between 0.07 and $0.64 \mathrm{mg} \mathrm{N}^{-1}$ in 2007 but the major part of rivers is included between 0.24 and $0.36 \mathrm{mg} \mathrm{N} \mathrm{1}^{-1}$. DIP concentrations are very low between 0.002

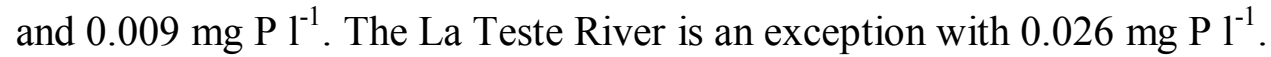

The water discharge to the Arcachon Bay of the Leyre River was $46710^{6} \mathrm{~m}^{3}$ in the year 2007 and $42610^{6} \mathrm{~m}^{3}$ in 2008. The discharge reached a maximum value of $65 \mathrm{~m}^{3} \mathrm{~s}^{-1}$ during winter 2007 and a minimum of $8 \mathrm{~m}^{3} \mathrm{~s}^{-1}$ during summer 2007. Nutrient fluxes were calculated for the years 2007 and 2008 and are summarized in Table 3. The total DIN flux is estimated to $836 \times 10^{3} \mathrm{~kg} \mathrm{~N}$ in 2007 and $969 \times 10^{3} \mathrm{~kg} \mathrm{~N}$ in 2008, the DON flux is estimated to $174 \times 10^{3} \mathrm{~kg} \mathrm{~N}$ in 2007 and the DIP flux is $4.8 \times 10^{3} \mathrm{~kg} \mathrm{P}$ in 2007 and $2.9 \times 10^{3} \mathrm{~kg} \mathrm{P}$ in 2008. The largest catchment that drains the Leyre River dominates overall in fluxes $(90 \%$ of the total DIN flux) and water discharge (78\% of the total water discharge). However, small catchments present specific fluxes. Catchments with farming areas (Cires, Milieu, Passaduy, Lanton, Renet) export much more nitrate than non-farming catchments (Aiguemorte, Tagon) despite similar water discharge. Nitrate is the main form of DIN and represents between 80 and $98 \%$ of DIN (Tab. 3) except in the Ponteil River (only 10\% in 2007). Ammonium flux from the Ponteil River represents $25 \%$ in 2007 and $14 \%$ in 2008 of the whole ammonium flux that reached the Arcachon lagoon. The Leyre River dominates the DIP flux.

The mean precipitation in 2008 was $984 \pm 17 \mathrm{~mm}$. The amount of water supplied by rainfall was compared to the stream flow so that an evaporation rate could be defined. The evaporation rate deduced from the Leyre River daily discharge was around $80 \%$, typical of a forestry catchment (Bosch \& Hewlett 1982; Vertessy et al. 2003). The evaporation rate must 
1 except for some of the highly farmed catchments. The average concentrations of nutrients in 2 rainwater deduced from sample analyses and the precipitations are $0.19 \mathrm{mg} \mathrm{N}^{-1}$ of nitrate,

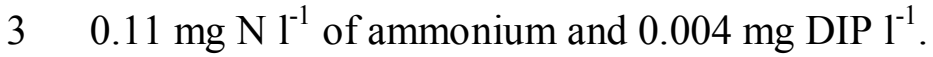

Nutrient budget between 1971 and 2008 based on the monitoring of the Leyre River (Auby et al. 1994) shows changes. DIN concentrations and fluxes increased (Fig. 2c,e), whereas DIP concentrations and fluxes decreased (Fig. 2d,f). The interannual nutrient concentration and flux variation was lower than the range of variation between 1970 and 2008. Major changes occurred between 1975 and 1993. During this period, DIN concentrations and fluxes became more than 3 times higher, from 0.33 to $1.2 \mathrm{mg}^{-1}$ (Fig. 2e), and from 203 to $608 \times 10^{3} \mathrm{kg-N}$ year $^{-1}$ (Fig. 2c) respectively. This change can be directly related to a change in cultivated surface areas in the catchment. From 1970 to present, the surface area assigned to intensive agriculture has continuously increased in the Leyre catchment according to the data providing by the French agricultural department (Fig. 2a). Simultaneously, the interannual variability has considerably increased. Since 1995, the increase in DIN concentrations and fluxes is lowered despite an increase in cultivated areas. The highest concentration is that reported for the year 2008. The ratio of rainfalls/water discharge increased during the last 15 years (Fig. 2b), suggesting a lowering of Leyre water discharge independent of rainfalls. DIP fluxes dropped from 28 to $4.3 \times 10^{3} \mathrm{~kg}_{\text {year }}{ }^{-1}$. Despite a high variability in concentrations and fluxes, DIP continuously decreased.

\section{Modeling the export rates}

The export rates are defined according to the typology based on land-use and summarized in Table 4. Based on the Aiguemorte catchment, forested parcel exports $45 \mathrm{~kg} \mathrm{~N}$ nitrate $\mathrm{km}^{-2}$ year ${ }^{-1}$. Based on the Cassy catchment the calculated export rate of deforested area is $93 \mathrm{~kg} \mathrm{~N}$-nitrate $\mathrm{km}^{-2}$ year $^{-1}$. Based on the Betey catchment the export rate of urban area is $62 \mathrm{~kg} \mathrm{~N}$-nitrate $\mathrm{km}^{-2}$ year ${ }^{-1}$. Based on farmed catchment Leyre, Cires, Milieu, and Passaduy the export rates of cultivated surfaces are 2800, 2900, 2400, and $3300 \mathrm{~kg} \mathrm{~N}$-nitrate $\mathrm{km}^{-2}$ year ${ }^{1}$, respectively, i.e. a mean of $2850 \mathrm{~kg} \mathrm{~N}$-nitrate $\mathrm{km}^{-2}$ year $^{-1}$. The mean export from forested, recently deforested, and farming areas as deduced from catchment slightly impacted by housing is 13 and $0.57 \mathrm{~kg} \mathrm{~km}^{-2}$ year $^{-1}$ for $\mathrm{N}$-ammonium and DIP, respectively. The export rates calculated from the La Teste catchment is indicative of a maximum urban area export. 
1 Then, urban areas export $100 \mathrm{~kg} \mathrm{~N}$-Ammonium $\mathrm{km}^{-2}$ year $^{-1}$ and $8.5 \mathrm{~kg} \mathrm{DIP} \mathrm{km}^{-2}$ year ${ }^{-1}$. The

2 DON export is due to the background concentration and equals to $63 \mathrm{~kg} \mathrm{~N} \mathrm{~km}^{-2}$ year ${ }^{-1}$.

The export rates are used to model the annual DIN flux and to validate the model by comparison with data ( $\mathrm{Tab} .3$ ). The ratio $\mathrm{Fm} / \mathrm{Fc}$ is close to 1 in the major part of streams for the 2007 year highlighting a good estimate. Two small catchments (Betey, Gujan) are badly modeled because the DIN source due to urban waste is not included in the calculation and the Ponteil catchment is badly modeled too. In 2008, the model is less exact but the main catchment (Leyre) is well modeled with a $\mathrm{Fm} / \mathrm{Fc}$ ratio equal to 1.2.

(1)

(10)

\section{Nitrogen mass balance}

The Figure 3 summarizes the nitrogen mass balance in cultivated pine forests and in cornfields. Inputs are atmospheric deposition, fertilizer, ammonification and nitrification of harvest wastes, and fixation. Outputs are denitrification, volatilization, sorption, harvest, and export by rivers. The two land-use have a different nitrogen mass balance. Fertilizer and harvest are the main nitrogen fluxes in cornfields, whereas atmospheric deposition, fixation and harvest dominate in forest ecosystem.

The amount of nitrogen assimilated in mature cornfields is between 22400 and 26400 $\mathrm{kg} \mathrm{N} \mathrm{km}{ }^{-2}$ year $^{-1}$ (Plénet \& Lemaire 1999). We consider that $60 \%$ is included in grain (Lemaire, comm. pers.) and harvested i.e. 13450 to $15850 \mathrm{~kg} \mathrm{~N} \mathrm{~km}^{-2}$ year $^{-1}$. Then $40 \%$ stay in situ and are mineralized during the next year i.e. 8950 to $10550 \mathrm{~kg} \mathrm{~N} \mathrm{~km}^{-2}$ year ${ }^{-1}$. The fixation rate in fields comes from Puckett et al. (1999), but it is not a value from the area studied here. In cornfields of the Arcachon Bay catchment the volatilization rate comes from Jambert et al. (1997), the fertilizer use from Agreste (2000), and the denitrification rate from Rimmelin (1998). In forests, Loustau et al. (1999) estimate the amount of nitrogen assimilated by a 50 -years pine forest equals to $50000 \mathrm{~kg} \mathrm{~N}$ including clear-cutting. This nitrogen is contained in trunks $(77 \%)$ and in residual parts of trees, mostly barks, or stumps $(23 \%)$ (Loustau et al. 1999). As a consequence a 50-years pine forest harvest exports $50000 \mathrm{~kg} \mathrm{~N}$. At the catchment scale, we consider that this value can be annualized. Then, pine harvesting exports $1000 \mathrm{~kg} \mathrm{~N} \mathrm{~km}^{-2}$ year $^{-1}$ or $770 \mathrm{~kg} \mathrm{~N} \mathrm{~km}^{-2}$ year $^{-1}$ if residual parts are not collected. We consider that residual parts may be a source of nitrogen by ammonification, i.e. $220 \mathrm{~kg} \mathrm{~N} \mathrm{~km}^{-2}$ year $^{-1}$. For maritime pine forests, the N-fixation rate from symbiotic gorse presented in the 
1 Figure 3 comes from Augusto et al. (2005). The estimated annual $\mathrm{N}_{2}$ fixation flux ranged

2 from 50 to $510 \mathrm{~kg} \mathrm{~N} \mathrm{~km}^{-1} \cdot \mathrm{year}^{-1}$ in the mature pine stands. In young open pine stand, the 3 gorse fixation may reach $5000 \mathrm{~kg} \mathrm{~N} \mathrm{~km}^{-1} \cdot \mathrm{year}^{-1}$. The denitrification rate comes from De Wit 4 et al. (2005), the volatilization rate from Jambert et al. (1994) and the fertilizer use from

\section{Discussion}

\section{Land use impact on biogeochemistry of the catchments}

The nutrient export rate is a function of several environmental parameters including land use (Sobota et al. 2009), hydrology (Obermann et al. 2007) and climate (Howarth et al. 2006). The main variable in the overall studied zone is land use and size of the catchments. Climate, precipitation, and lithology are homogeneous. Relationships between land use and the average nutrient concentration show an obvious positive correlation between the percentage of farming area and the average concentration of nitrate (Fig. 4a). The average nitrate concentration reaches up to $3.5 \mathrm{mg} \mathrm{l}^{-1}$ when farming areas occupy more than $20 \%$ of the catchment. Thus, nitrate appears as a strong signature of farming areas. Many studies have demonstrated the role of fertilizers in farming areas as a cause of high DIN export in the water system (Galloway 2003; Garcia-Esteves et al. 2007). DON concentrations are lower than DIN concentrations and do not correlate with farming area highlighting that fields of the Arcachon catchment export more nutrients as inorganic species. The dominance of DIN versus DON is classically observed for south European regions (Lorite-Herrera et al. 2009) whereas north European fields preferentially export nutrients as organic species (Agedah et al. 2009; Stedmon et al. 2006).

Average ammonium and DIP concentrations are correlated with the percentage of housing areas, with correlation coefficient equal to 0.836 and 0.734 respectively (Fig. 4b,c). The correlation between ammonium concentration and housing area excludes the Ponteil 
1 catchment, which seems to have an atypical behavior (Canton et al. 2010). Wastewaters of the

2 cities around the Arcachon Bay are collected, treated and flushed out the lagoon. We have observed, however, a slight effect of housing on the quality of streamwaters. It may partially be due to urban runoff. Nevertheless, DIP concentrations are very low in comparison with major French rivers, with 0.025 to $0.047 \mathrm{mg} \mathrm{l}^{-1}$ reported in the Garonne River (Deborde et al. 2007; Muylaert et al. 2009) and $0.062 \mathrm{mg} \mathrm{l}^{-1}$ reported for the Loire River (Moatar \& Meybeck 2005). Due to a large amount of iron oxides and humic particles the Landes de Gascogne soils are favorable to DIP sorption (Qualls et al. 2002). Hence, the DIP export is highly limited. Wastewaters of the municipalities located upstream of the Leyre River are treated and flushed into the river. Moreover, the wastewater collect of the small littoral catchments is more efficient than those of the Leyre catchment. This may explain the relatively high concentrations of DIP in the Leyre River versus the small littoral catchments. Consequently, DIP and ammonium originate mostly from point sources related to urban area, but the wastewater discharge in the river system is highly changeable.

Pine forests are known to export fewer nutrients than grassland or fields (Benoit et al. 1995; Onderka et al. 2009), by limiting runoff and leakage of nutrients. The cultivated pine forest of the studied area does not receive fertilizers, except a phosphorus fertilization before plantation (Blanco 1994). DON represents up to $65 \%$ of the total nitrogen export in strictly non-farmed catchments. This ratio between DON and DIN is frequently observed in forest ecosystems (Hedin \& Johnson 1995; Perakis \& Hedin 2002) except in highly anthropized forests (Campbell et al. 2000). Dominance of DON export is explained by an efficient denitrification and uptake in riparian zone, which decreases the DIN export (Vink et al. 2007) and because riparian zone is a source of DON from root exudation (Hagedorn et al. 2001). In the Arcachon Bay catchment, DON concentration does not characterize forested surfaces, because we have observed no correlation between these two parameters (Fig. 4d). The main part of the studied catchments contain between 70 and $80 \%$ of forested area but DON concentrations are between 0.07 and $0.63 \mathrm{mg}^{-1}$ and the most often between 0.21 and $0.35 \mathrm{mg}$ $1^{-1}$. Then DON should be rather a background concentration of all soil type leaching. 
1 A moderate eutrophication was observed in the Arcachon lagoon during the eighties in late 2 spring and summer (Auby et al. 1994). The most significant change among primary producers was the development of the allochtonous green algae Monostroma obscurum. The biomass of this macro algae reached 18000 to $21000 \times 10^{3} \mathrm{~kg}$ in spring during the eighties and the nineties (Auby et al. 1994). The proliferation was due to eutrophication of the lagoon and the invasive development of the algae. Moreover, Monostroma obscurum is highly competitive, particularly in P-limiting conditions, and can store nutrients to build resistance during the oligotrophic period (Auby et al. 1994). The European projects CLEAN (Coastal Lagoon Eutrophication and Anaerobic Processes, 1996) and ROBUST (the ROle of BUffering capacities in STabilising coastal lagoon ecosystems, 1996-1999) have contributed toward characterizing the origin and effect of eutrophication in the Bay (Castel et al. 1996; De Wit et al. 2001): the increase in nutrient discharge originating from continent was the major cause of eutrophication. This eutrophication was partially buffered by Zostera noltii meadows and Arcachon Bay sediments, the both acting as sink of nutrient. In addition to the nutrient concentration, the low residual currents favoured eutrophication. The average residence time of water ranges from 12.5 to 15.9 days in the Arcachon Bay (Plus et al. 2009). It contrasts, for example, with the bay of Brest, also located in the French Atlantic coast, which is well resistant to eutrophication as the hydrodynamics allows quick dispersion of living matter and nutrients (Le Pape et al. 1996), despite very high inputs of continental DIN. The residence time of fresh waters makes the Arcachon Bay very sensitive to the change of nutrient fluxes with time. Presently, blooms of macro algae are no longer reported and the primary production is now dominated by the microphytobenthos and phytoplankton (Glé et al. 2007), and the natural meadows of Zostera noltii (Auby 1991) although, the DIN flux has not decreased since the eighties (Fig. 2c). However, the DIP flux has decreased (Fig 2d). It suggests that the past high fluxes of DIP were responsible for the summer blooms. Another point of view is to consider a biological feedback due to the macro algae proliferation, regardless of nutrient input. After a rapid proliferation for years, the introduced species may have found a biological steady state including a regulation due to predation.

Since 1995 the DIN flux has been more or less stable. This is not due to the stabilization of the agricultural surface area. This surface area has continuously increased since 1970 (Fig 2a), which probably explains a continuously increase in DIN concentrations (Fig. 2e). The fact is that the Leyre River water discharge has slightly decreased (Fig. 2b), which may be the reason for the relative stabilization in DIN fluxes. The ratio of 
1 Leyre water discharge, independent of rainfalls. This low water discharge may be due to 2 cornfield irrigation. DIN fluxes stabilization might be also the consequence of a better control 3 in fertilizer use. The decrease in DIP fluxes and concentrations must be the consequence of wastewater management improvement during these decades. As a consequence the eutrophication risk is probably as high as that during the eighties. The recent regression of Zostera noltii meadows (Plus et al. 2010), however, may increase the eutrophication risk because these meadows buffer the nutrient loads (De Wit et al. 2001).

The quality of atmospheric deposition is more or less constant. The DIN flux in 2008 was $287 \mathrm{~kg} \mathrm{~N}-\mathrm{km}^{-2}$ year $^{-1}$. This represents half the value of the atmospheric DIN flux reported by Auby et al. (1994) but the same order of that reported by Collos et al. (1989). Despite the high variability, these values are between pristine sites, (Owens et al. 1992) and coastal and anthropized areas (Cornell et al. 1995). The Arcachon lagoon comes under the category of preserved sites but not pristine. Consequently, atmospheric depositions are not a cause of eutrophication of the lagoon at the present time.

\section{Nitrogen mass balance validation and assessment of the} durability of maize and pine crop

The export rates are calculated from one year of samplings in rivers and analyses. As a consequence, they describe the nutrient export during a short time and may not be applicable for every year. The nitrate export rate due to forest parcel (45 kg N-nitrate $\mathrm{km}^{-2}$ year ${ }^{-1}$ ) is comparable to the value of $38 \mathrm{~kg} \mathrm{~N}$-nitrate $\mathrm{km}^{-2}$ year $^{-1}$ reported for the Tagon catchment (De Wit et al. 2005). In 2007-2008, the export rate of the Tagon catchment reached $88 \mathrm{~kg} \mathrm{~N}$ nitrate $\mathrm{km}^{-2}$ year ${ }^{-1}$, suggesting that an additional source of nitrate was present in this catchment, probably linked to deforested parcels. Our result suggests that tree harvesting increases the nitrate export (93 kg N-nitrate $\mathrm{km}^{-2}$ year $^{-1}$ ), as reported for alpine forests (Bäumler \& Zech 1999) and temperate forests (Likens et al. 1970). For instance, the export rate reported for the Hubbard Brook forest was $142{\mathrm{~kg} \mathrm{~N} \text {-nitrate } \mathrm{km}^{-2} \text { year }}^{-1}$ within two years following the deforestation (Likens et al. 1970). The export rates of cultivated surfaces are 2800, 2900, 2400, and $3300 \mathrm{~kg} \mathrm{~N}$-nitrate $\mathrm{km}^{-2}$ year $^{-1}$ in Leyre, Cires, Milieu, and Passaduy catchments, respectively i.e. a mean of $2850 \mathrm{~kg} \mathrm{~N}$-nitrate $\mathrm{km}^{-2}$ year $^{-1}$. Differences between 
1 catchments may be due to the kind and history of farming. Indeed, cornfields dominates the

2 farming areas, but vegetable and flowers fields occupy about $30 \%$ of farming surfaces. The

3 DIN export rate certainly depends on this land-use parameter. The size of the watershed should probably also be taken into account. The Leyre catchment is larger than the other catchments: cornfields are located far from the sampling station. As a consequence the Leyre river may loss a part of nitrate by plant uptake or denitrification along the riverbed.

The modeled nitrate flux is in very good agreement with the measured nitrate flux for the Leyre River in 2007 and good in 2008 (Tab. 3). The differences between modeled and measured fluxes are higher for Cires and Milieu catchments. Several authors have demonstrated that nutrient fluxes increases with river discharge due to intensification of runoff and leaching (Dumont et al. 2005; Holloway \& Dahlgren 2001; Obermann et al. 2007; Probst 1985; Schaefer et al. 2009). The calculated nitrate export rate does not include the variations of stream water discharge. It may explain the difference between 2007 and 2008 particularly in small catchments, because they are more reactive to flood events. The well modeled Leyre River represents $90 \%$ of the total DIN flux toward the Arcachon Bay. Therefore the nitrate export rate due to farming parcels is a good approximation for this first nitrogen mass balance.

The mineralization rate may be overestimated because we consider that the total biomass of maize stems and leaves is mineralized. However nitrogen may be lost in refractory organic matter or by grazing. The denitrification rate under cornfields may be overestimated too. Although a high potential of denitrification was measured (Rimmelin 1998) the low amount of organic carbon in soils is highly limiting (De Wit et al. 2005).

Since the different sinks and sources of nitrogen are estimated with large error margins, we discuss several budgets. In cornfields, the maximum nitrogen input is about $31400 \mathrm{~kg} \mathrm{DIN} \mathrm{km}^{-2}$ year $^{-1}$ and the minimum is equal to $27800 \mathrm{~kg} \mathrm{DIN} \mathrm{km}^{-2}$ year $^{-1}$. The maximum nitrogen output is equal to about $27600 \mathrm{~kg}^{\mathrm{DIN} \mathrm{km}} \mathrm{kear}^{-1}$ and the minimum is equal to $25000 \mathrm{~kg}^{\mathrm{DIN} \mathrm{km}} \mathrm{km}^{-2}$ year $^{-1}$. Considering these results cornfields gain nitrogen. The benefit is between 200 and $6400 \mathrm{~kg}^{\mathrm{DIN} \mathrm{km}} \mathrm{year}^{-1}$. The excess of DIN input may be compensated by storage as organic nitrogen forms. This organic nitrogen is not exported by rivers, as demonstrated above, and may be stored in soil. Howarth et al. (2006) have observed nitrogen storage in soils, which occurred preferentially during dry years; nitrogen was flushed during wet years. Moreover, we assume that the mineralization rate of leaves and stems of maize is overestimated because a part may be stored. Fixation should be overestimated too because we do not have data from the studied area. Since fertilizer is the main source of DIN 
and nitrogen is in excess, the fertilizer use should be reduced. DIN export by river represents

2 between 4.8 and $5.4 \%$ of the total nitrogen cycle in cornfields and between 3.3 and $4.2 \%$ in

3 pine forest. It suggests that cornfields are more impacted by DIN leaching and run-off.

We identify only two sinks of nitrogen in mature pine forest: harvest and river export. Forest harvesting is the major sink of nitrogen but it depends of the fate of barks. If barks are harvested then nitrogen output is equal to about $1060 \mathrm{~kg}^{\mathrm{DIN} \mathrm{km}}{ }^{-2}$ year $^{-1}$ and nitrogen input is between 350 and $810 \mathrm{~kg} \mathrm{DIN} \mathrm{km}{ }^{-2}$ year $^{-1}$. If barks are not harvested then nitrogen output is equal to $830 \mathrm{~kg} \mathrm{DIN} \mathrm{km}^{-2}$ year ${ }^{-1}$ and nitrogen input is between 570 and $1030 \mathrm{~kg} \mathrm{DIN} \mathrm{km}^{-2}$ year $^{-1}$. The DIN budget in forest is highly variable because of the wide interval of values for $\mathrm{N}$-fixation rates. Nitrogen outputs are generally higher than inputs. Consequently the cultivated pine forest is not sustainable. However, the $\mathrm{N}_{2}$-fixation rate may be underestimated and in-situ measurements are needed in order to validate this mass balance.

\section{Conclusion}

A detailed study of small catchments enables a mechanistic approach of nutrient dynamics in relation to land use. Such an approach has already been followed in the area considered in this study for the Ponteil and the Tagon Rivers (Canton et al. 2010; De Wit et al. 2005). Data on nutrient fluxes as well as land use analysis of all the catchments allowed us to provide an estimate of continental dissolved $\mathrm{N}$ and $\mathrm{P}$ fluxes to the Arcachon Bay and to connect export by rivers to land use.

We emphasize a net impact of land-use on stream water quality. Agriculture is the major source of nitrogen for the lagoon and it has a robust signature on stream water. Farming parcels export $2863 \mathrm{~kg} \mathrm{DIN} \mathrm{km}^{-2}$ year $^{-1}$ including $99.5 \%$ of nitrate. This average rate permits a good prevision of the DIN flux in the larger catchment (Leyre River) but it is less accurate in smaller catchment due to high interannual variability. It permits to obtain, however, a good assessment of the nitrate flux entering in the lagoon, since the Leyre River represents a total of $90 \%$ of the continental DIN flux. The nitrate flux modeling can be improved by the integration of stream water discharge especially in small catchment. We have estimated the nitrate export rate originating from forest parcels and deforested parcels to 45 and $93 \mathrm{~kg} \mathrm{~N}$ 
$1 \mathrm{~km}^{-2}$ year ${ }^{-1}$, respectively. The ammonium and DIP export rates are independent of land-use 2 and equal to $13 \mathrm{~kg} \mathrm{~N} \mathrm{~km}^{-2}$ year $^{-1}$ and $0.57 \mathrm{~kg} \mathrm{P} \mathrm{km}^{-2}$ year $^{-1}$ respectively. Nutrient export by 3 urban area is highly variable depending of the quality of wastewater treatment. DON has a 4 background concentration independent of land-use.

This study completes and unifies several studies. (i) First, it permits to have a longterm view of land-use and nutrient budget change. The nitrogen flux has increased between 1970 and 1995 and it is more or less constant since 1995 because of the decrease in stream water discharge. Thus the increase in irrigation due to maize cultivation limits nitrogen exportation. Of course, this should probably have an unknown impact on the budget of the freshwater in the Arcachon lagoon. The DIP flux has decreased continuously since 1970 due to wastewater treatment improvement. As a consequence the risk of eutrophication of the Arcachon Bay is now reduced in comparison with the eighties. (ii) Secondly, this study permits to establish and compare the nitrogen budget in cornfields and cultivated pine forest. We highlight that the nitrogen management is not optimal in cornfields and the soils store between 200 and $6400 \mathrm{~kg}$ DIN km$^{-2}$ year $^{-1}$. Therefore, the fertilizer use should be reduced. The nitrogen budget in cultivated forest emphasizes that the soils may lose nitrogen when harvesting is done every 50 years and if the fixation rate is minimum. However, the nitrogen

\section{Acknowledgements}

The authors would like to thank S. Bichon, N. Molnar, N. LeCorre, A. Coussot, S. Bujan, A. Riberi, and J. Deborde for their assistance during sampling campaigns and laboratory work, Victoria N. Deycard for help with the English version, and an anonymous reviewer for his helpful comments. We thank the Syndicat Intercommunal du Bassin d'Arcachon (SIBA): P. Capdeville for fruitful discussions and R. Genet and G. Regazzoni for providing data. Furthermore, we wish to thank S. Zaragosi and V. Hanquiez for providing information on GIS software. We thank Daniel Plénet and Gilles Lemaire for fruitful discussion concerning nitrogen cycling in cornfields. This work was funded by a Region Aquitaine Ph.D. fellowship to M.C. We gratefully acknowledge the financial support of the French program PNEC-Littoral Atlantique, and the ANR PROTIDAL. 


\section{Figure captions}

3 Figure 1: General view and soil occupation in the Arcachon Bay catchment. Soil occupation

4 is determined by analyzing plane photography in Geographic Information System (GIS).

5 Catchment boundaries are defined in Laplana (1992).

7 Figure 2: Change in nutrient export by the Leyre River and catchment characteristics between $8 \quad 1970$ and 2008. (a) shows the change in farming surface area in $\mathrm{km}^{2}$; (b) shows the change of 9 rainfalls/water discharge ratio; (c) shows the change of DIN flux in $10^{3}{\mathrm{~kg}-\mathrm{N} . y e a r^{-1}}^{-}$(d) shows

10 the change of DIP flux in $10^{3} \mathrm{~kg}^{\mathrm{P}} \mathrm{P} \cdot \mathrm{year}^{-1}$; (e) shows the change of DIN concentration in $11 \mu \mathrm{mol} . \mathrm{L}^{-1}$; (f) shows the change of DIP concentration in $\mu \mathrm{mol}^{-\mathrm{L}^{-1}}$. White diamonds are data 12 originating from Auby (1991), Laplana (1992), and Ifremer surveys, and black squares are 13 from the present study

15 Figure 3: Comparison of nitrogen mass balance in two agro ecosystems, cornfield and 16 cultivated pine forest. The dark grey symbolizes nitrogen output and the slight grey 17 symbolizes nitrogen input.

19 Figure 4: Typology based on land use and nutrient concentrations. (a) shows the relation 20 between average nitrate concentrations by catchment and farming area; (b) shows the relation 21 between average ammonium concentrations by catchment and housing area; (c) shows the 22 relation between average dissolved inorganic phosphorus concentrations by catchment and 23 farming area; and (d) shows the relation between average dissolved organic nitrogen 24 concentrations by catchment and forest area. 
1 Agedah EC, Binalaiyifa HE, Ball AS, Nedwell DB (2009) Sources, turnover and bioavailibility

2 of dissolved organic nitrogen in the Colne estuary, UK. Marine Ecology Progress Series 382:

$3 \quad 23-33$

4AGRESTE (2000) Recensements agricoles. In. Ministère de l'Agriculture.

5 Anderson L (1979) Simultaneous spectrophotometric determination of nitrite and nitrate by flow

6 injection analysis. Analytica Chimica Acta 110: 123-128

7 Auby I (1991) Contribution à l'étude des herbiers de Zostera noltii dans le Bassin d'Arcachon :

8 dynamique, production et dégradation, macrofaune associée. In. University of Bordeaux. $p$

9234

10 Auby I, Labourg PJ (1996) Seasonal dynamics of Zostera noltii Hornem. In the Bay of Arcachon 11 (France). Journal of Sea Research 35(4): 269-277

12 Auby I, Manaud F, Maurer D, Trut G (1994) Etude de la prolifération des algues vertes dans le 13 bassin d'Arcachon. Report Prepared by IFREMER, Arcachon, France, for CEMAGREF-SSA14 SABARC: $1-163$

15 Augusto L, Crampon N, Saur E, Bakker MR, Pellerin S, De Lavaissière C, Trichet P (2005) High 16 rates of nitrogen fixation of Ulex species in the understory of maritime pine stands and the 17 potential effect of phosphorus fertilization. Canadian Journal of Forest Research 35(5): 1183$18 \quad 1192$

19Bäumler R, Zech W (1999) Effects of forest thinning on the streamwater chemistry of two forest 20 watersheds in the Bavarian Alps. Forest Ecology and Management 116(1-3): 119-128

21 Benoit M, Saintot D, Gaury F (1995) Mesures en parcelles d'agriculteurs des pertes en nitrates. 22 Variabilité sous divers systèmes de culture et modélisation de la qualité de l'eau d'un bassin 23 d'alimentation. In: C.R. Acad. Agr. p 175-188

24Billen G, Garnier J, Némery J, Sebilo M, Sferratore A, Barles S, Benoit P, Benoît M (2007) A 25 long-term view of nutrient transfers through the Seine river continuum. Science of the Total 26 Environment 375(1-3): 80-97

27Blanco C (1994) Le pin maritime, son environnement, sa culture, les facteurs climatiques et 28 fongiques responsables de son affaiblissement. In. University Bordeaux 2, Bordeaux. p 68

29Bosch JM, Hewlett JD (1982) A review of catchment experiments to determine the effect of 30 vegetation changes on water yield and evapotranspiration. Journal of Hydrology 55(1-4): 3-23

31 Campbell JL, Hornbeck JW, McDowell WH, Buso DC, Shanley JB, Likens GE (2000) Dissolved 32 organic nitrogen budgets for upland, forested ecosystems in New England. Biogeochemistry 33 49(2): 123-142

34Canton M, Anschutz P, Naudet V, Molnar N, Mouret A, Franceschi M, Naessens F, Poirier D 35 (2010) Impact of solid waste disposal on nutrient dynamics in a sandy catchment. Journal of 36 Contaminant Hydrology 116(1-4): 1-15

37Castel J, Caumette P, Herbert R (1996) Eutrophication gradients in coastal lagoons as 38 exemplified by the Bassin d'Arcachon and the Etang du Prévost. Hydrobiologia 329(1-3):

39Collos Y, Souchu P, Tréguer P (1989) Relationships between different forms of inorganic 40 nitrogen in rainwater of a coastal area and ground-level gaseous nitrogen oxides. Atmospheric 41 Research 23(2): 97-104

42 Conley DJ, Schelske CL, Stoermer EF (1993) Modification of the biogeochemical cycle of silica 43 with eutrophication. Marine Ecology Progress Series 101(1-2): 179-192 
1 Cornell S, Rendell A, Jickells T (1995) Atmospheric inputs of dissolved organic nitrogen to the 2 oceans. Nature 376(6537): 243-246

3 De Wit R, Leibreich J, Vernier F, Delmas F, Beuffe H, Maison P, Chossat JC, Laplace-Treyture 4 C, Laplana R, Clave V, Torre M, Auby I, Trut G, Maurer D, Capdeville P (2005) Relationship 5 between land-use in the agro-forestry system of les Landes, nitrogen loading to and risk of 6 macro-algal blooming in the Bassin d'Arcachon coastal lagoon (SW France). Estuarine, 7 Coastal and Shelf Science 62(3 SPEC. ISS.): 453-465

8De Wit R, Stal LJ, Lomstein BA, Herbert RA, Van Gemerden H, Viaroli P, Cecherelli VU, 9 Rodriguez-Valera F, Bartoli M, Giordani G, Azzoni R, Schaub B, Welsh DT, Donnelly A, 10 Cifuentes A, Anton J, Finster K, Nielsen LB, Pedersen AGU, Neubauer AT, Colangelo MA, 11 Heijs SK (2001) Robust: The role of buffering capacities in stabilising coastal lagoon 12 ecosystems. Continental Shelf Research 21(18-19): 2021-2041

13Deborde J, Anschutz P, Chaillou G, Etcheber H, Commarieu MV, Lecroart P, Abril G (2007) 14 The dynamics of phosphorus in turbid estuarine systems: Example of the Gironde estuary 15 (France). Limnology and Oceanography 52(2): 862-872

16Diaz RJ, Rosenberg R (2008) Spreading dead zones and consequences for marine ecosystems. 17 Science 321(5891): 926-929

18Duarte CM (1995) Submerged aquatic vegetation in relation to different nutrient regimes 19 Ophelia 41: 87-112

20Dumont E, Harrison JA, Kroeze C, Bakker EJ, Seitzinger SP (2005) Global distribution and 21 sources of dissolved inorganic nitrogen export to the coastal zone: Results from a spatially 22 explicit, global model. Global Biogeochemical Cycles 19(4):

23Falkowski PG, Barber RT, Smetacek V (1998) Biogeochemical controls and feedbacks on ocean 24 primary production. Science 281(5374): 200-206

25Galloway JN (1998) The global nitrogen cycle: changes and consequences. Environmental 26 Pollution 102(1, Supplement 1): 15-24

27 Galloway JN (2003) The Global Nitrogen Cycle. In: Elsevier (ed) Treatise on Geochemistry. p $28 \quad 557-583$

29 Garcia-Esteves J, Ludwig W, Kerhervé P, Probst J-L, Lespinas F (2007) Predicting the impact of 30 land use on the major element and nutrient fluxes in coastal Mediterranean rivers: The case of 31 the Têt River. Applied Geochemistry 22(1): 230-248

32 Glé C, Del Amo Y, Sautour B, Laborde P, Chardy P (2007) Variability of nutrients and 33 phytoplankton primary production in a shallow macrotidal coastal ecosystem (Arcachon Bay, 34 France). Estuarine, Coastal and Shelf Science 76(3): 642-656

35 Groffman PM, Tiedje JM (1989) Denitrification in north temperate forest soils: Relationships 36 between denitrification and environmental factors at the landscape scale. Soil Biology and 37 Biochemistry 21(5): 621-626

38Hagedorn F, Bucher JB, Schleppi P (2001) Contrasting dynamics of dissolved inorganic and 39 organic nitrogen in soil and surface waters of forested catchments with Gleysols. Geoderma 40 100(1-2): 173-192

41Hedin AJ, Johnson A (1995) Patterns of nutrient loss from unpolluted, oldgrowth temperate 42 forests: evaluation of biogeochemical theory. Ecology 76: 493-509

43 Holloway JM, Dahlgren RA (2001) Seasonnal and event-scale variations in solute chemistry for 44 four Sierra Nevada catchments. Journal of Hydrology 206: 106-121 
1 Howarth RW (2008) Coastal nitrogen pollution: A review of sources and trends globally and 2 regionally. Harmful Algae 8(1): 14-20

3 Howarth RW, Marino R (2006) Nitrogen as the limiting nutrient for eutrophication in coastal 4 marine ecosystems: Evolving views over three decades. Limnology and Oceanography 51(1 5 II): $364-376$

6Howarth RW, Swaney DP, Boyer EW, Marino R, Jaworski N, Goodale C (2006) The influence 7 of climate on average nitrogen export from large watersheds in the Northeastern United 8 States. Biogeochemistry 79(1-2): 163-186

9Jambert C, Delmas RA, Labroue L, Chassin P (1994) Nitrogen compound emissions from 10 fertilized soils in a maize field pine tree forest agrosystem in the southwest of France. Journal 11 of Geophysical Research 99(D8):

12 Jambert C, Serça D, Delmas R (1997) Quantification of N-losses as NH3, NO, and N2O and N2 13 from fertilized maize fields in southwestern France. Nutrient Cycling in Agroecosystems 14 48(1-2): 91-104

15Laplana R, Billy F, Beuffe H, Fleuranceau F (1992) Localisation, quantification et dynamique 16 des apports de nutriments au Bassin d'Arcachon. Localisation, Quantification et Dynamique 17 des Apports de Nutriments au Bassin d'Arcachon 66:

18Le Pape O, Del Amo Y, Menesguen A, Aminot A, Quequiner B, Treguer P (1996) Resistance of 19 a coastal ecosystem to increasing eutrophic conditions: The Bay of Brest (France), a semi20 enclosed zone of Western Europe. Continental Shelf Research 16(15): 1885-1907

21 Legigan P (1979) L'élaboration de la formation du Sable des Landes, dépot résiduel de 22 l'environnement sédimentaire pliocène-pléistocène centre aquitain. In. Université de 23 Bordeaux, Bordeaux. p 429

24Likens EG, Bormann FH, Johnson MN, Fisher DW, Pierce SR (1970) Effects of Forest Cutting 25 and Herbicide Treatment on Nutrient Budgets in the Hubbard Brook Watershed-Ecosystem. 26 Ecological Monographs 40(1): 23-47

27Lorite-Herrera M, Hiscok K, Jiménez-Espinosa R (2009) Distribution of Dissolved Inorganic and 28 Organic Nitrogen in river water and groundwater in an agriculturally-dominated catchment, 29 south-east Spain. Water Air Soil Pollution 2009(198): 335-346

30Loustau D, Bert D, Trichet P (1999) Fonctionnement primaire et productivité de la forêt landaise 31 : implication pour une gestion durable. Revue Forestière Française 51(5): 571-592

32Ludwig W, Probst JL (1998) River sediment discharge to the oceans; present-day controls and 33 global budgets. American Journal of Science 298: 265-295

34Mantoura RFC, Martin JM, Wollast R (1991) Ocean margin processes in global change. Report 35 of the Dahlem workshop, Berlin, March 1990.

36Meybeck M, Helmer R (1989) The quality of rivers: From pristine stage to global pollution. 37 Global and Planetary Change 1(4): 283-309

38Meybeck M, Ragu A Presenting the GEMS-GLORI, a compendium of world river discharge to 39 the oceans. In: Freshwater Contamination. Rabat. 1997. vol 243. p 3-14

40Moatar F, Meybeck M (2005) Compared performances of different algorithms for estimating 41 annual nutrient loads discharged by the eutrophic River Loire. Hydrological Processes 19(2): $42 \quad 429-444$ 
1 Mullin JB, Riley JP (1955) The colorimetric determination of silicate with special reference to 2 sea and natural waters. Analytica Chimica Acta 12: 162-176

3 Murphy J, Riley JP (1962) A modified single solution method for the determination of phosphate 4 in natural waters. Analytica Chimica Acta 27: 31-36

5 Muylaert K, Sanchez-Pérez JM, Teissier S, Sauvage S, Dauta A, Vervier P (2009) Eutrophication 6 and its effect on dissolved Si concentrations in the Garonne River (France). Journal of 7 Limnology 68(2): 368-374

8 Nixon SW, Buckley B, Granger S, Bintz J (2001) Responses of very shallow marine ecosystems 9 to nutrient enrichment. Human \& Ecological Risk Assessment 7: 1457-1481

10Obermann M, Froebrich J, Perrin JL, Tournoud MG (2007) Impact of significant floods on the 11 annual load in an agricultural catchment in the mediterranean. Journal of Hydrology 334(1-2): 12 99-108

13Onderka M, Pekarova P, Miklanek P, Halmova D, Pekar J (2009) Examination of the Dissolved 14 Inorganic Nitrogen Budget in Three Experimental Microbasins with Contrasting Land Cover15 A Mass Balance Approach. Water, Air, and Soil Pollution: 1-10

16Owens NJP, Galloway JN, Duce RA (1992) Episodic atmospheric nitrogen deposition to 17 oligotrophic oceans. Nature 357(6377): 397-399

18Perakis S, Hedin AJ (2002) Fluxes and fates of nitrogen in soil of an unpolluted old-growth 19 temperate forest, southern Chile. Ecology 82: 2245-2260

20Plénet D, Lemaire G (1999) Relationships between dynamics of nitrogen uptake and dry matter 21 accumulation in maize crops. Determination of critical N concentration. Plant and Soil 216(122 2): $65-82$

23Plus M, Dalloyau S, Trut G, Auby I, de Montaudouin X, Emery E, Noël C, Viala C (2010) Long24 term evolution (1988-2008) of Zostera spp. meadows in Arcachon Bay (Bay of Biscay). 25 Estuarine, Coastal and Shelf Science 87: 357-366

26Plus M, Dumas F, Stanisière JY, Maurer D (2009) Hydrodynamic characterization of the 27 Arcachon Bay, using model-derived descriptors. Continental Shelf Research 29(8): 1008$28 \quad 1013$

29Probst JL (1985) Nitrogen and Phosphorus exportation in the Garonne Basin (France). Journal of 30 Hydrology 76(3-4): 281-305

31 Puckett LJ, Cowdery TK, Lorenz DL, Stoner JD (1999) Estimation of nitrate contamination of an 32 agro ecosystem outwash aquifer using a nitrogen mass balance budget. Journal of 33 Environmental Quality 28: 2015-2025

34Qualls RG, Haines BL, Swank WT, Tyler SW (2002) Retention of soluble organic nutrients by a 35 forested ecosystem. Biogeochemistry 61(2): 135-171

36Rimmelin P (1998) Etude des apports allochtones d'azote inorganique dissous parvenant à un 37 système lagunaire : le Bassin d'Arcachon. In. University Bordeaux 1, Bordeaux.

38Rimmelin P, Dumon JC, Maneux E, GonCalves A (1998) Study of Annual and Seasonal 39 Dissolved Inorganic Nitrogen Inputs into the Arcachon Lagoon, Atlantic Coast (France). 40 Estuarine, Coastal and Shelf Science 47(5): 649-659

41 Saint Pe MA (1966) Etude Hydrogéologique et Géochimique: la Nappe Phréatique du Nord-est 42 du Bassin d'Arcachon et son Influence sur l'Alimentation des Aquifères Sous-Jacents. In. 43 Université de Bordeaux. p 439 
1 Schaefer SC, Hollibaugh JT, Alber M (2009) Watershed nitrogen input and riverine export on the 2 west coast of the US. Biogeochemistry 93(3): 219-233

3 Smith VH (2003) Eutrophication of freshwater and coastal marine ecosystems: A global problem. 4 Environmental Science and Pollution Research 10(2): 126-139

5 Sobota DJ, Harrison JA, Dahlgren RA (2009) Influences of climate, hydrology, and land use on 6 input and export of nitrogen in California watersheds. Biogeochemistry 94(1): 1-20

7Stedmon CA, Markaker S, Søndergaard M, Vang T, Laubel A, Borch NH (2006) Dissolved

8 organic matter export to a temperate estuary; seasonal variations and implications of land-use.

9 Estuarine, Coastal and Shelf Science 29: 388-400

10Strickland JDH, Parsons TR (1972) A pratical handbook of seawater analysis. Bulletin of 11 Fisheries Research Board of Canada:

12 Valderrama JC (1981) The simultaneous analysis of total nitrogen and total phosphorus in natural 13 waters. Marine Chemistry 10(2): 109-122

14 Valiela I, McClelland J, Hauxwell J, Behr PJ, Hersh D, Foreman K (1998) Macroalgal blooms in 15 shallow estuaries: Controls and ecophysiological and ecosystem consequences. Limnology 16 and Oceanography 42(5 II): 1105-1118

17Vertessy RA, Zhang L, Dawes WR (2003) Plantations, river flows and river salinity. Australian 18 Forestry 66(1): 55-61

19Vink S, Ford PW, Bormans M, Kelly C, Turley C (2007) Contrasting nutrient exports from a 20 forested and an agricultural catchment in south-eastern Australia. Biogeochemistry 84(3): $21 \quad 247-264$

22 Walling DE, Webb BW (1985) Estimating the discharge of contaminants to coastal waters by 23 rivers: some cautionary comments. Marine Pollution Bulletin 16(12): 488-492 

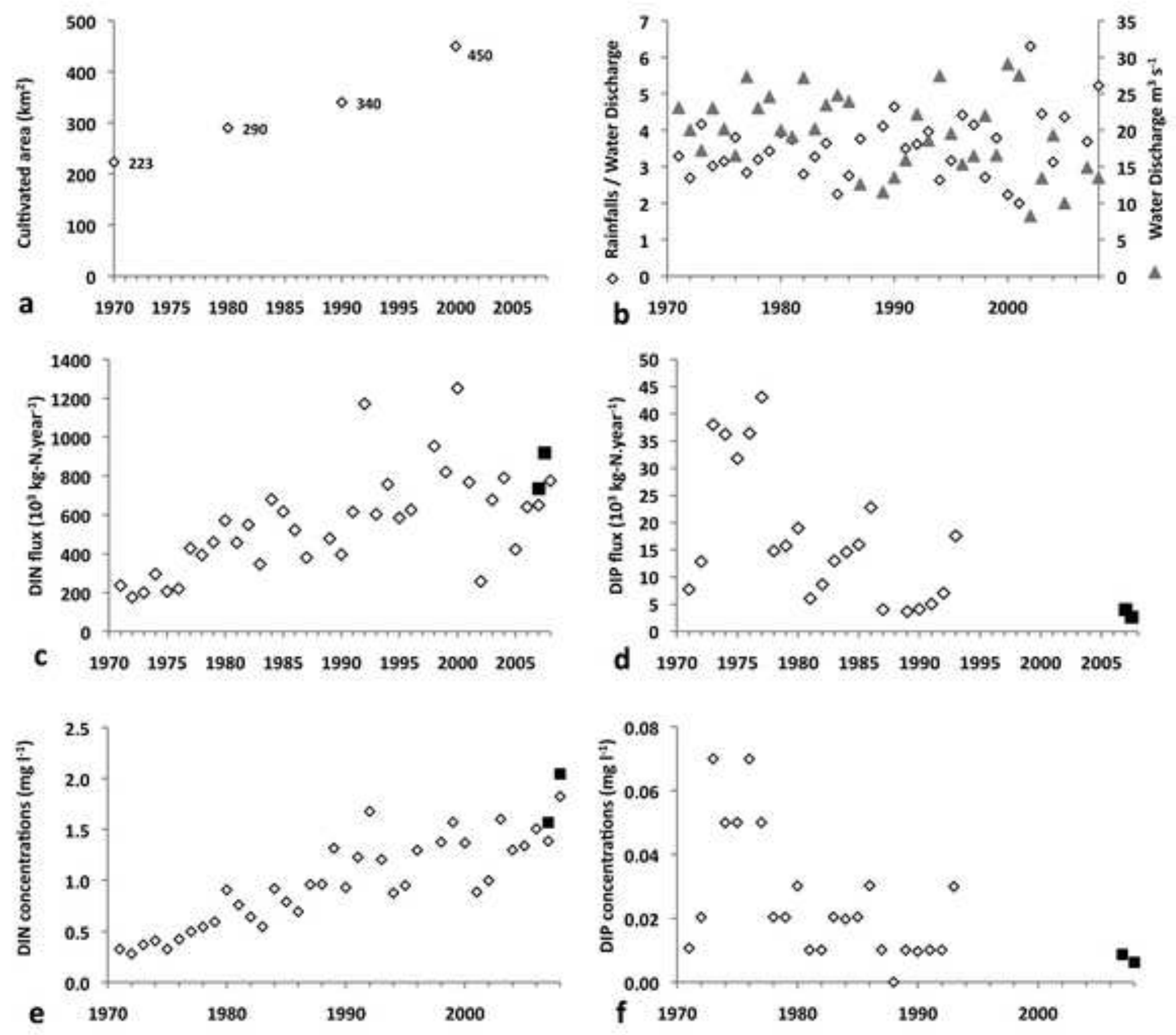


\section{Figure 3}

Click here to download high resolution image

\section{Nitrogen mass balance in cornfields}

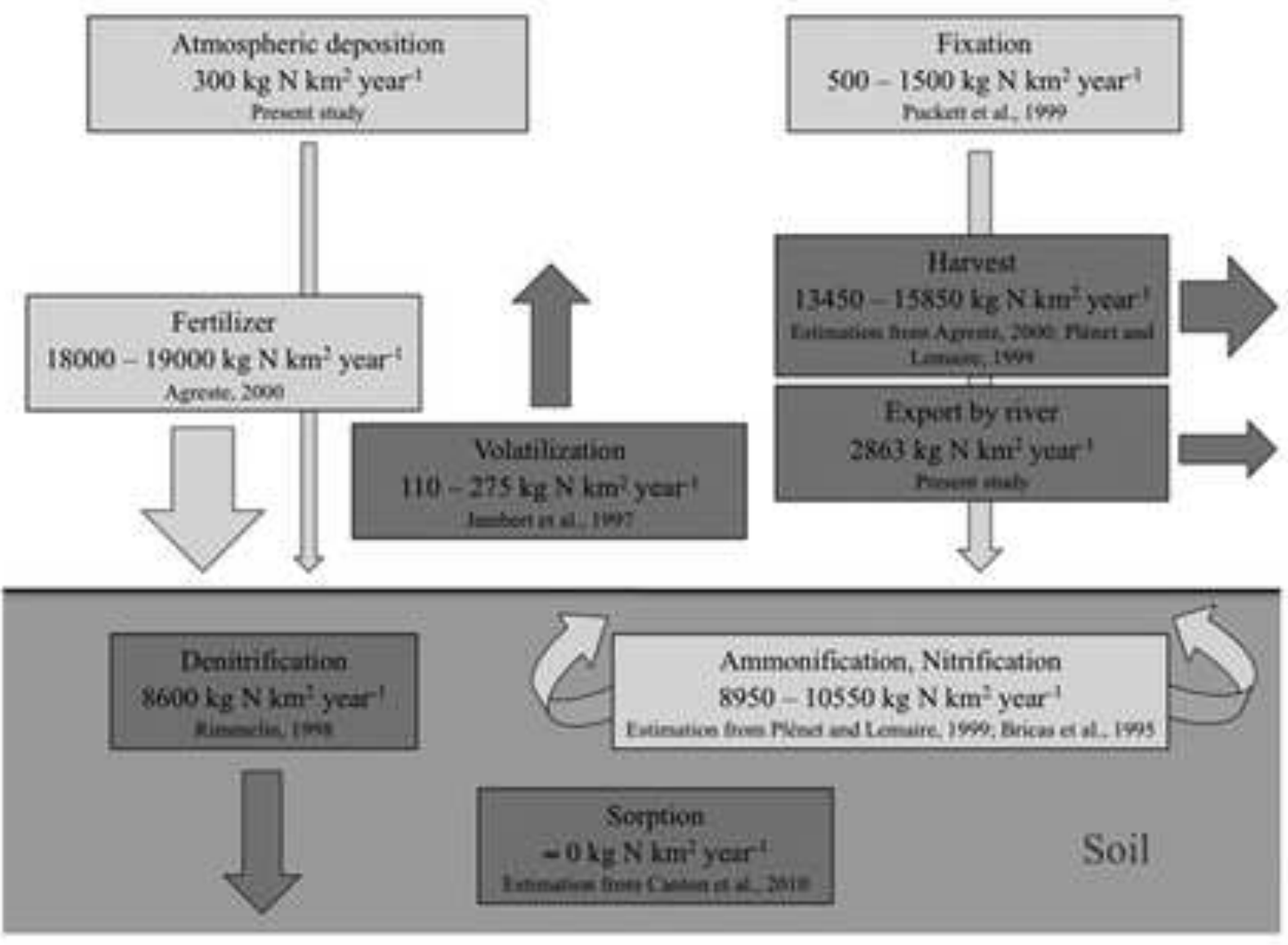

Nitrogen mass balance in pine forest

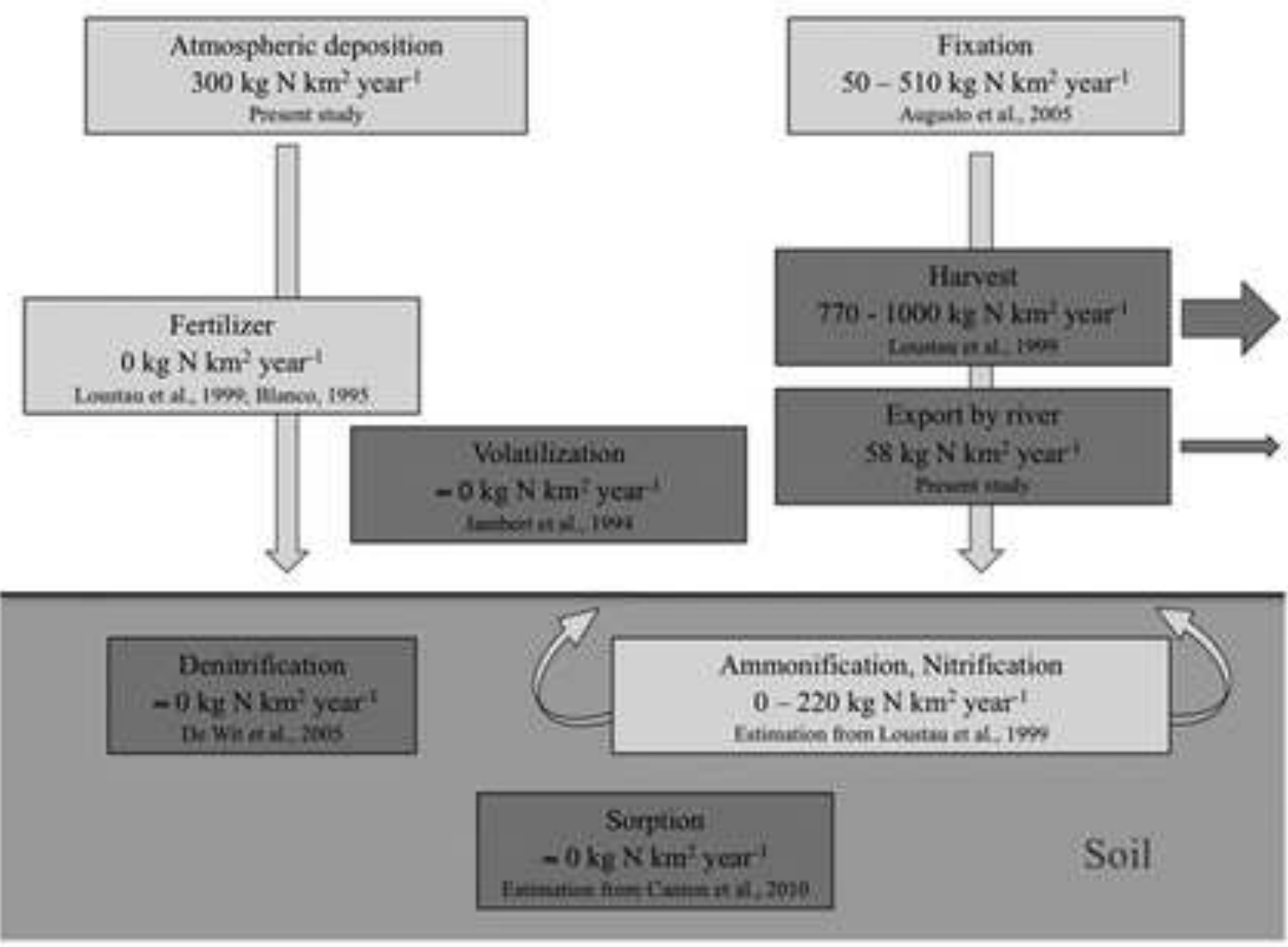


Click here to download high resolution image
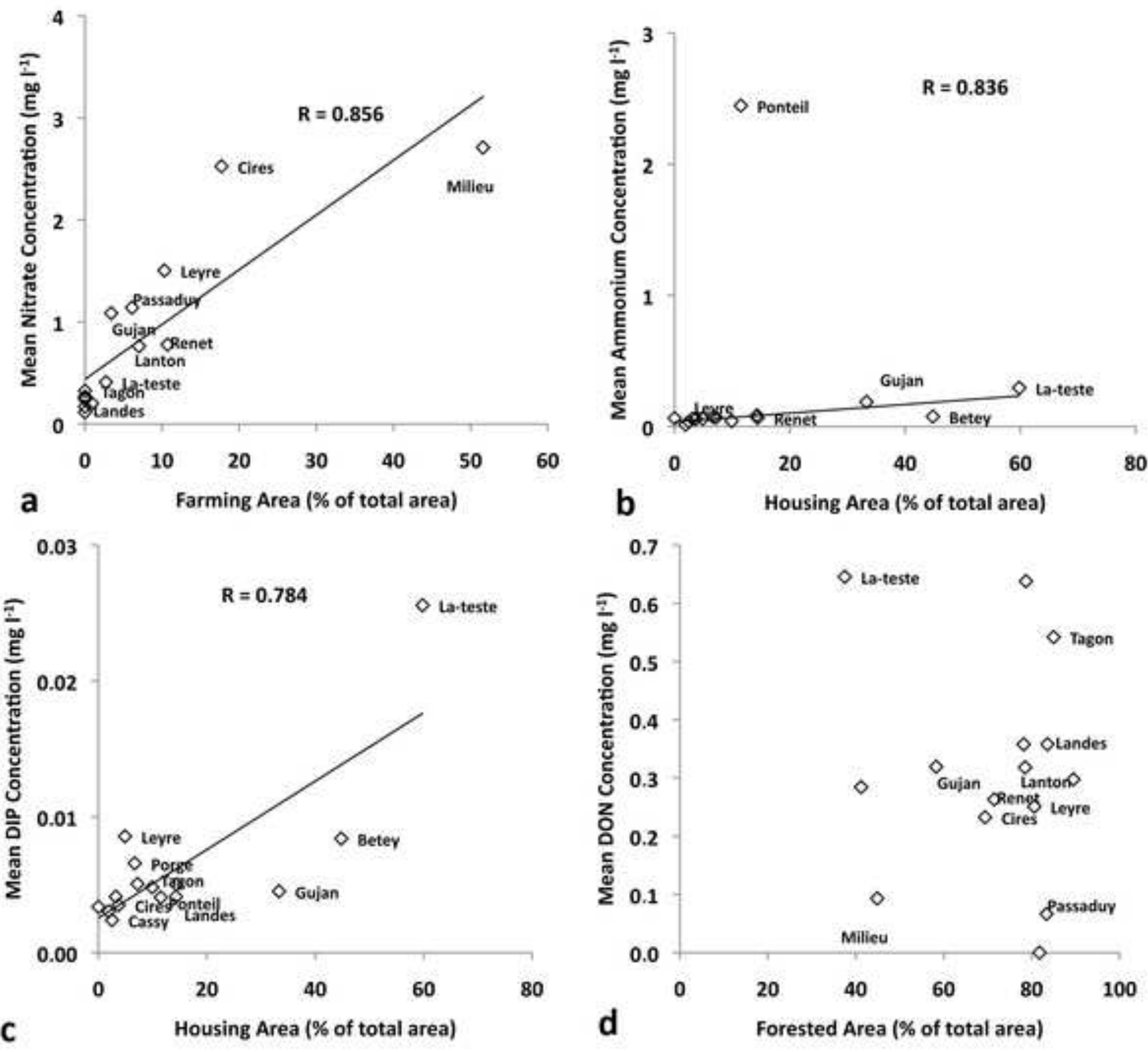

b Housing Area (\% of total area)

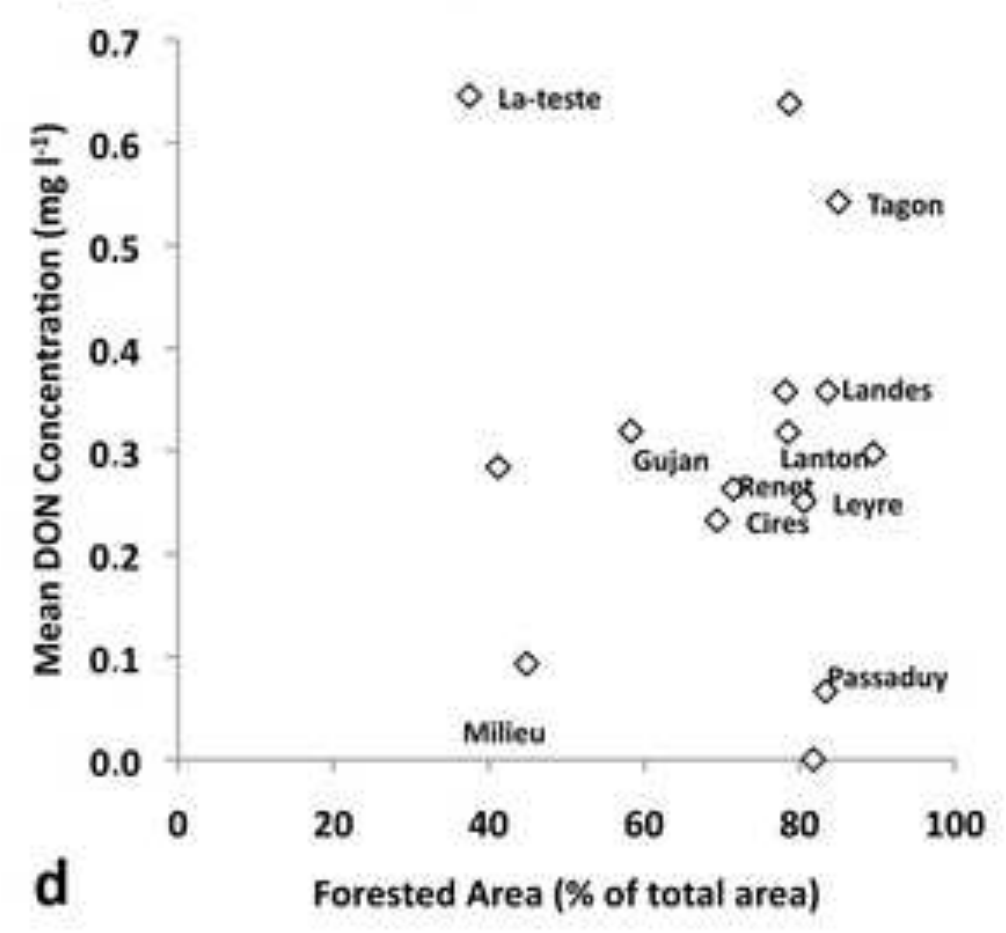


Table 1: Proportion of land use categories in the Arcachon Bay catchment

\begin{tabular}{|c|c|c|c|c|c|c|c|c|c|c|c|c|c|c|c|}
\hline Name & Aiguemorte & Betey & Cassy & Cires & Gujan & Landes & Lanton & $\begin{array}{c}\text { La } \\
\text { Teste }\end{array}$ & Leyre & Milieu & Passaduy & Ponteil & Porge & Renet & Tagon \\
\hline $\begin{array}{l}\text { Area } \\
\left(\mathrm{km}^{2}\right)\end{array}$ & 25.6 & 15.6 & 22.8 & 48.7 & 29.1 & 87.4 & 36.1 & 11.2 & 2141.3 & 17.4 & 21.3 & 23.3 & 221.6 & 17.9 & 29.6 \\
\hline $\begin{array}{c}\text { Farming } \\
(\%)\end{array}$ & 0.0 & 0.0 & 0.0 & 17.7 & 3.4 & 0.0 & 7.0 & 2.7 & 10.3 & 51.6 & 6.1 & 0.0 & 0.9 & 10.7 & 0.0 \\
\hline $\begin{array}{c}\text { Newly } \\
\text { deforested } \\
(\%)\end{array}$ & 3.3 & 14.0 & 19.3 & 9.2 & 5.0 & 2.2 & 11.2 & 0.0 & 4.2 & 3.6 & 8.6 & 6.7 & 13.7 & 3.5 & 5.1 \\
\hline $\begin{array}{c}\text { Housing } \\
(\%)\end{array}$ & 7.2 & 44.8 & 2.5 & 3.7 & 33.3 & 14.3 & 3.2 & 59.8 & 4.9 & 0.0 & 1.9 & 11.5 & 6.7 & 14.4 & 9.9 \\
\hline $\begin{array}{c}\text { Forest } \\
(\%)\end{array}$ & 89.5 & 41.2 & 78.2 & 69.4 & 58.3 & 83.6 & 78.5 & 37.5 & 80.6 & 44.9 & 83.4 & 81.8 & 78.7 & 71.5 & 85.0 \\
\hline
\end{tabular}


Table 2 : Mean nutrient concentrations in streamwater (mg-N and mg-P ${ }^{-1}$ ) in 2007 and 2008. The mean is calculated from two years of survey in 15 catchments.

\begin{tabular}{|c|c|c|c|c|c|c|c|c|c|c|c|c|c|c|c|}
\hline 2007 & $\begin{array}{c}\text { Aiguemort } \\
\mathrm{e}\end{array}$ & $\begin{array}{c}\text { Bete } \\
\mathrm{y}\end{array}$ & $\begin{array}{c}\text { Cass } \\
\mathrm{y}\end{array}$ & $\begin{array}{c}\text { Cire } \\
\mathrm{s} \\
\end{array}$ & $\begin{array}{c}\text { Guja } \\
n\end{array}$ & $\begin{array}{c}\text { Lande } \\
\mathrm{s}\end{array}$ & $\begin{array}{c}\text { Lanto } \\
n\end{array}$ & $\begin{array}{c}\mathrm{La} \\
\text { teste }\end{array}$ & $\begin{array}{c}\text { Leyr } \\
\mathrm{e}\end{array}$ & $\begin{array}{c}\text { Milie } \\
\mathrm{u}\end{array}$ & $\begin{array}{c}\text { Passadu } \\
\mathrm{y}\end{array}$ & $\begin{array}{c}\text { Pontei } \\
1\end{array}$ & $\begin{array}{c}\text { Porg } \\
\mathrm{e}\end{array}$ & $\begin{array}{c}\text { Rene } \\
\mathrm{t}\end{array}$ & $\begin{array}{c}\text { Tago } \\
\mathrm{n}\end{array}$ \\
\hline 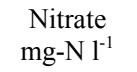 & 0.17 & 0.27 & 0.24 & 2.52 & 1.09 & 0.11 & 0.76 & 0.41 & 1.50 & 2.70 & 1.13 & 0.27 & 0.20 & 0.78 & 0.32 \\
\hline $\begin{array}{l}\text { Ammoniu } \\
\mathrm{m} \mathrm{mg-N}^{-1}\end{array}$ & 0.07 & 0.08 & 0.04 & 0.06 & 0.19 & 0.09 & 0.06 & 0.30 & 0.06 & 0.06 & 0.02 & 2.45 & 0.07 & 0.07 & 0.04 \\
\hline $\begin{array}{c}\text { DON } \\
\text { mg-N }^{-1}\end{array}$ & 0.29 & 0.28 & 0.35 & 0.24 & 0.32 & 0.36 & 0.32 & 0.64 & 0.25 & 0.10 & 0.07 & - & 0.63 & 0.27 & 0.55 \\
\hline $\begin{array}{c}\text { DIP } \\
\text { mg-P 1 }^{-1} \\
\end{array}$ & 0.005 & $\begin{array}{c}0.00 \\
8 \\
\end{array}$ & $\begin{array}{c}0.00 \\
2 \\
\end{array}$ & $\begin{array}{c}0.00 \\
3 \\
\end{array}$ & 0.005 & 0.004 & 0.004 & 0.026 & $\begin{array}{c}0.00 \\
9 \\
\end{array}$ & 0.003 & 0.003 & 0.004 & $\begin{array}{c}0.00 \\
7 \\
\end{array}$ & $\begin{array}{c}0.00 \\
5 \\
\end{array}$ & 0.005 \\
\hline \multicolumn{16}{|l|}{2008} \\
\hline 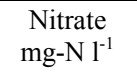 & - & - & - & 4.82 & - & 0.06 & 0.91 & - & 1.99 & 3.29 & - & 0.38 & 0.20 & 1.37 & 0.17 \\
\hline $\begin{array}{l}\text { Ammoniu } \\
\mathrm{m} \mathrm{mg-N}^{-1}\end{array}$ & - & - & - & 0.06 & - & 0.06 & 0.07 & - & 0.06 & 0.11 & - & 1.10 & 0.13 & 0.07 & 0.15 \\
\hline $\begin{array}{c}\text { DIP } \\
\text { mg-P } 1^{-1}\end{array}$ & - & - & - & $\begin{array}{c}0.00 \\
3 \\
\end{array}$ & - & 0.002 & 0.008 & - & $\begin{array}{c}0.00 \\
6\end{array}$ & 0.002 & - & 0.004 & $\begin{array}{c}0.00 \\
2\end{array}$ & $\begin{array}{c}0.00 \\
6\end{array}$ & 0.006 \\
\hline
\end{tabular}


Table 3: Nutrient fluxes at the 15 river mouths in 2007 and 2008. Nutrient fluxes are calculated from our data. $\mathrm{Fm} / \mathrm{Fc}$ is the ratio between the measured DIN flux and the modelized DIN flux. The calculation of the modelized flux is based on the surface area of each land-use and the corresponding export rate but it excludes the DIN flux due to urban area because this export rate can't apply to the overall urban area.

\begin{tabular}{|c|c|c|c|c|c|c|c|c|c|c|c|c|c|c|c|c|}
\hline 2007 & Aiguemorte & Betey & Cassy & Cires & Gujan & Landes & Lanton & $\begin{array}{l}\mathrm{La} \\
\text { Teste }\end{array}$ & Leyre & Milieu & Passaduy & Ponteil & Porge & Renet & Tagon & Total \\
\hline $\begin{array}{l}\text { Nitrate } \\
\left(10^{3} \mathrm{~kg}-\mathrm{N}\right)\end{array}$ & 1.0 & 0.9 & 1.2 & 27.0 & 6.9 & 2.2 & 6.0 & 1.0 & 707 & 10.3 & 5.3 & 1.3 & 9.8 & 3.1 & 2.1 & 785 \\
\hline $\begin{array}{c}\text { Ammonium } \\
\left(10^{3} \mathrm{~kg}-\mathrm{N}\right)\end{array}$ & 0.4 & 0.3 & 0.2 & 0.6 & 1.2 & 1.6 & 0.5 & 0.7 & 28.2 & 0.2 & 0.1 & 12.5 & 3.5 & 0.3 & 0.3 & 51 \\
\hline $\begin{array}{c}\text { DON } \\
\left(10^{3} \mathrm{~kg}-\mathrm{N}\right)\end{array}$ & 1.7 & 1.0 & 1.8 & 2.5 & 2.0 & 6.9 & 2.5 & 1.6 & 118 & 0.4 & 0.3 & - & 31.0 & 1.0 & 3.5 & 174 \\
\hline $\begin{array}{c}\text { DIP } \\
\left(10^{3} \mathrm{~kg}-\mathrm{P}\right)\end{array}$ & 0.03 & 0.03 & 0.01 & 0.04 & 0.03 & 0.08 & 0.03 & 0.06 & 4.03 & 0.01 & 0.01 & 0.02 & 0.32 & 0.02 & 0.03 & 4.8 \\
\hline $\begin{array}{c}\mathrm{DIN} \\
\mathrm{Fm} / \mathrm{Fc}\end{array}$ & 1.2 & 0.5 & 1.1 & 1.0 & 0.5 & 1.2 & 1.4 & 0.7 & 1.0 & 2.5 & 0.9 & 0.1 & 1.4 & 1.9 & 0.7 & - \\
\hline \multicolumn{17}{|l|}{2008} \\
\hline $\begin{array}{c}\text { Nitrate } \\
\left(10^{3} \mathrm{~kg}-\mathrm{N}\right)\end{array}$ & - & - & - & 46.6 & - & 1.1 & 6.5 & - & 846 & 11.4 & - & 1.8 & 8.7 & 4.9 & 1.0 & 928 \\
\hline $\begin{array}{l}\text { Ammonium } \\
\left(10^{3} \mathrm{~kg}-\mathrm{N}\right)\end{array}$ & - & - & - & 0.5 & - & 1.1 & 0.5 & - & 26.9 & 0.4 & - & 5.1 & 5.6 & 0.2 & 0.9 & 41 \\
\hline $\begin{array}{c}\text { DON } \\
\left(10^{3} \mathrm{~kg}-\mathrm{N}\right)\end{array}$ & - & - & - & - & - & - & - & - & - & - & - & - & - & - & - & - \\
\hline $\begin{array}{c}\text { DIP } \\
\left(10^{3} \mathrm{~kg}-\mathrm{P}\right)\end{array}$ & - & - & - & 0.03 & - & 0.04 & 0.06 & - & 2.64 & 0.01 & - & 0.02 & 0.09 & 0.02 & 0.03 & 2.9 \\
\hline $\begin{array}{c}\mathrm{DIN} \\
\mathrm{Fm} / \mathrm{Fc}\end{array}$ & - & - & - & 1.7 & - & 0.5 & 0.8 & - & 1.2 & 0.4 & - & 5.4 & 0.8 & 0.8 & 1.2 & - \\
\hline
\end{tabular}


Click here to download Table: Table-4.doc

Table 4: Mean export rates by land-use

\begin{tabular}{|c|c|c|c|c|}
\hline & Agriculture & Forest & Deforested area & Urban area \\
\hline $\begin{array}{c}\text { Nitrate } \\
\mathrm{kg} \mathrm{N} \mathrm{km}^{-2} \text { year }^{-1}\end{array}$ & 2850 & 45 & 93 & 62 \\
\hline $\begin{array}{c}\text { Ammonium } \\
\mathrm{kg} \mathrm{N} \mathrm{km}^{-2} \text { year }^{-1}\end{array}$ & & 13 & & Up to100 \\
\hline $\begin{array}{c}\text { DIP } \\
\mathrm{kg} \mathrm{P} \mathrm{km}^{-2} \text { year }^{-1}\end{array}$ & & 0.57 & & Up to 8.5 \\
\hline $\begin{array}{c}\text { DON } \\
\mathrm{kg} \mathrm{N} \mathrm{km}^{-2} \text { year }^{-1}\end{array}$ & & & & \\
\hline
\end{tabular}

